\title{
Cytotoxicity and Antibacterial Potential of Halogenated Chamigrenes from Malaysian Red Alga, Laurencia majuscula
}

(c) (1) $\odot$

Authors

Takashi Kamada ${ }^{1,2}$, Chin-Soon Phan', Tatsufumi Okino ${ }^{3}$, Charles Santhanaraju Vairappan ${ }^{1}$

\section{Affiliations}

1 Laboratory of Natural Products Chemistry, Institute for Tropical Biology and Conservation, Universiti Malaysia Sabah, Jalan UMS, 88450 Kota Kinabalu, Sabah, Malaysia

2 Laboratory of Natural Products Chemistry, Department of Materials and Life Science, Faculty of Science and Technology, Shizuoka Institute of Science and Technology, Fukuroi, Shizuoka 437-8555, Japan

3 Graduate School of Environmental Science, Faculty of Environmental Earth Science, Hokkaido University, Sapporo 060-0810, Japan

\section{Key words}

Laurencia majuscula, Rhodomelaceae, red alga, halogenated, chamigrane sesquiterpene

$\begin{array}{ll}\text { received } & 05.03 .2019 \\ \text { revised } & 08.07 .2019 \\ \text { accepted } & 15.07 .2019\end{array}$

Bibliography

DOI https://doi.org/10.1055/a-0977-4418

Planta Med Int Open 2019; 6: e36-e40

(c) Georg Thieme Verlag KG Stuttgart · New York ISSN 2509-9264

\author{
Correspondence \\ Prof. Dr. Charles Santhanaraju Vairappan \\ Laboratory of Natural Products Chemistry \\ Institute for Tropical Biology and Conservation \\ Universiti Malaysia Sabah \\ Jalan UMS \\ 88400 Kota Kinabalu \\ Sabah \\ Malaysia \\ Tel.: + 60/88/320 000 ext. 2384, Fax: +6088320291 \\ csv@ums.edu.my
}

$\bigoplus \begin{aligned} & \text { Supplementary Material for this article is available } \\ & \text { online at http://www.thieme-connect.de/products. }\end{aligned}$

\begin{abstract}
Red algae of the genus Laurencia have been known to produce a wide array of bioactive secondary metabolites. Here, we report the isolation of two new halogenated chamigrenes, lauremantanones $A(\mathbf{1})$ and $B(\mathbf{2})$, along with seven known compounds, dendroidiol (3), (+)-elatol (4), cartilagineol (5), obtusol (6), ( + )-laurencenone B (7), 2-chloro-3-hydroxy- $\alpha$ chamigren-9-one (8), and puertitol A (9), from a population of Laurencia majuscula (Harvey) Lucas from Mantanani Island (North Borneo). The structures of the two new metabolites were determined based on spectroscopic data (IR, 1D and 2D NMR, and MS). Compounds isolated from this alga exhibited potent cytotoxic (HeLa, MCF-7, P-388) and antibacterial (against antibiotic-resistant clinical bacteria) activities. The major metabolite of this population has significant importance in the geographical distribution of this species globally.
\end{abstract}

\section{Introduction}

Red algae of the genus Laurencia are known to produce an array of diverse halogenated secondary metabolites represented as terpenoid, alkaloid and $C_{15}$-acetogenin chemical skeletons [1-4]. Presence and quantity of the major halogenated metabolites within Laurencia populations often vary with their species and geographical distribution [5-9]. Halogenated compounds have also been shown to exhibit various biological activities with pharmaceutical importance, such as antibacterial [7], cytotoxic [10], and insect repellent activities [11]. As part of our ongoing effort to document the diversity of halogenated secondary metabolites, we collected a population of Laurencia majuscula from the coastal waters of North Borneo (Mantanani Island), which led to the isolation of two new sesquiterpenoids, lauremantanones A (1) and B (2), along with 
seven known compounds, dendroidiol (3) [12], ( + )-elatol (4) [13], cartilagineol (5) [14-16], obtusol (6) [15-17], (+)-laurencenone $B(7)[18,19], 2$-chloro-3-hydroxy- $\alpha$-chamigren-9-one $(8)[13,20]$, and puertitol $A(\mathbf{9})$ [21] ( $\mathbf{F i g . ~ 1 ) . ~ H e r e i n , ~ w e ~ d e s c r i b e ~ t h e ~ i s o l a - ~}$ tion, structural elucidation, cytotoxicity, and antibacterial activities of these compounds.

\section{Results and Discussion}

Compound 1 was isolated as colorless oil, $[\alpha]_{D} 28+22.3$ (c 1.0, $\mathrm{CHCl}_{3}$ ). The molecular formula was established as $\mathrm{C}_{15} \mathrm{H}_{21} \mathrm{ClO}_{2}$ by the HRESIMS $[\mathrm{M}+\mathrm{H}]^{+}$ion at $m / z 269.1305$ (calcd. for $\mathrm{C}_{15} \mathrm{H}_{22} \mathrm{ClO}_{2}$, 269.1303) and it accounted for 5 degrees of unsaturation. Its IR absorption was seen at 3420 and $1650 \mathrm{~cm}^{-1}$, indicating the presence of hydroxyl $(-\mathrm{OH})$ and $\alpha, \beta$ unsaturated carbonyl $(C=O)$ functionalities. The ${ }^{13} \mathrm{C}$ NMR revealed the presence of 15 signals whose multiplicities were attributed by DEPT-135 and HSQC spectra to three methyls, five methylenes, including an oxygenated methylene, a trisubstituted, and a tetrasubstituted olefins, two quaternary carbons, and a carbonyl carbon. These signals accounted for three degrees of unsaturation, implying 1 possesses a bicyclic system. The NMR data ( $\triangleright$ Table $\mathbf{1}$ ) of $\mathbf{1}$ closely resembled that of $\mathbf{7}$ except for the replacement of a vinyl methyl at C-14 in 7 by a vinyl carbinol moiety in $1[18,19,22]$. The presence of a carbinol unit was further confirmed by its deshielded chemical shifts at C-14 $\left(\delta_{C} 64.0 ; \delta_{H}\right.$ 4.24) [23], IR absorption at $3420 \mathrm{~cm}^{-1}$, and HRESIMS spectrum.

The ${ }^{1} \mathrm{H}-{ }^{1} \mathrm{H}$ COSY ( $>$ Fig. 1S, Supporting Information) correlation between $\mathrm{H}_{2}-4$ and $\mathrm{H}_{2}-5$, together with the $\mathrm{HMBC}$ ( $\vee$ Fig. 1S, Supporting Information) correlations from $\mathrm{H}_{3}-12,13$ to $\mathrm{C}-6,10,11$, from $\mathrm{H}_{3}-15$ to $\mathrm{C}-2,3,4$, from $\mathrm{H}_{2}-14$ to $\mathrm{C}-6,7,8$, from $\mathrm{H}_{2}-1$ to $\mathrm{C}-2$, 5,6 , from $\mathrm{H}_{2}-10$ to $\mathrm{C}-9$, and from $\mathrm{H}-8$ to $\mathrm{C}-10$ were enough to es- tablish the planar structure of an $\alpha$-chamigrane-type sesquiterpenoid for 1 . The relative configuration at $C-6$ was assigned $S$ * , identical to that of $(+)-7$, based on a chemical shift $\left(\delta_{C} 46.4\right)$ and the optical rotation $[\alpha]_{\mathrm{D}}{ }^{25}+39.4\left(\mathrm{c} 0.2, \mathrm{CHCl}_{3}\right)$ as well as a biogenetic pathway given the fact that both compounds were isolated from the same specimen. ( $>$ Fig. $\mathbf{2 S - 7 S ) ~}$

Compound 2 was isolated as colorless oil, $[\alpha]_{\mathrm{D}}^{28}-35.0$ (c 0.5 , $\mathrm{CHCl}_{3}$ ). The molecular formula was determined as $\mathrm{C}_{15} \mathrm{H}_{23} \mathrm{ClO}_{3}$ through the HRESIMS [M + H] ${ }^{+}$ion at $\mathrm{m} / \mathrm{z} 287.1412$ (calcd. for $\left.\mathrm{C}_{15} \mathrm{H}_{24} \mathrm{ClO}_{3}, 287.1409\right)$. Both hydroxyl and carbonyl functionalities were detected by IR absorption at 3444 and $1651 \mathrm{~cm}^{-1}$, respectively. Upon careful comparison, NMR data of $\mathbf{2}(\triangleright$ Table $\mathbf{1}$ ) were almost identical to those of $\mathbf{8}$ except for the replacement of an olefinic methyl at C-14 in 8 by a vinyl carbinol unit in $\mathbf{2}$ [13]. Detailed assignment of ${ }^{1} \mathrm{H}-{ }^{1} \mathrm{H}$ COSY and $\mathrm{HMBC}$ correlations ( $/$ Fig. $1 \mathbf{S}$, Supporting Information) revealed an $\alpha$-chamigrane framework for 2. (॰ Fig. 8S-13S)

The relative stereochemistry of $\mathbf{2}$ was determined by NOESY experiments. The NOESY correlations between $\mathrm{H}-2 / \mathrm{H}_{2}-4 \alpha, \mathrm{H}-2 / \mathrm{H}_{3}-$ 15 , and $\mathrm{H}_{2}-4 \alpha / \mathrm{H}_{3}-15$ demonstrated that these protons were located on the same orientation, while both $2-\mathrm{Cl}$ and $3-\mathrm{OH}$ were located on the opposite orientation of the ring $B$. The relative configuration at C-6 was identical to that of (-)-8 based the NOE correlation between $\mathrm{H}_{2}-1 / \mathrm{H}_{3}-12$, chemical shifts, and the optical rotation $[\alpha]_{D}^{25}-46.0$ (c 0.22) [13]. The methylene $\mathrm{H}_{2}-14\left(\delta_{H} 4.46\right.$ and 4.42) of 2 experienced a downfield shift of $0.2 \mathrm{ppm}$ and was presented as an individual signal instead of superimposed as compared to that of $1\left(\delta_{H} 4.24, \mathrm{H}_{2}-14\right)$. This could be due to the additional hydroxyl moiety in $\mathbf{2}$ at $\mathrm{C}-3$, which results in a restricted rotation of the sigma bond between C-7 and C-14. Finally, judging from the co-occurrence of $\mathbf{2}$ and $\mathbf{8}$ in the same alga, the relative
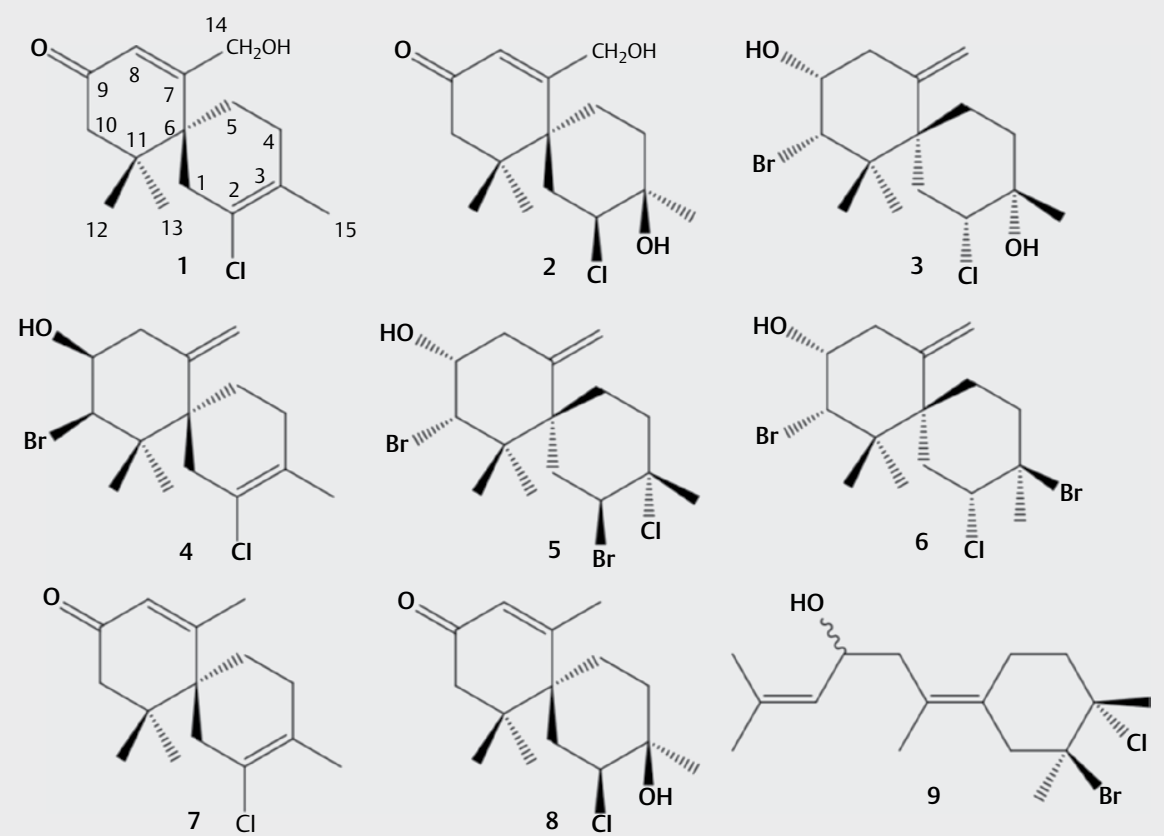

- Fig. 1 Structures of sesquiterpenoids 1-9 from L. majuscula. 
stereochemistry of the $B$ ring in $\mathbf{2}$ is the same as that of $\mathbf{8}$. Therefore, $2 S^{*}, 3 R^{*}$, and $6 S^{*}$ were assigned similarly to those of (-)-8. The natural product designated as laurencenone $B$ [22] was incorrectly assigned due to discrepancies that existed between published ${ }^{1} \mathrm{H}$ NMR data of the natural product and that of a synthetic compound [19]. Since then, no report of complete NMR and specific rotation measurements for the natural product laurencenone $B$ (7) was found, therefore, herein, we reported its specific rotation and ${ }^{1} \mathrm{H}$ and ${ }^{13} \mathrm{C}$ NMR data. The specific rotation and ${ }^{1} \mathrm{H}$ and ${ }^{13} \mathrm{C}$ NMR data of 7 were consistent to semisynthetic and synthetic materials $[13,19] .(>$ Fig. 14S-15S)

The $\alpha$-chamigrane-type sesquiterpenoids $\mathbf{1}$ and $\mathbf{2}$ showed strong cytotoxic activities against HeLa and P-388 cell lines with an $I_{50} \leq 5.0 \mu \mathrm{g} / \mathrm{mL}$ ( $>$ Table 2 ), whereas $\beta$-chamigrane-type sesquiterpenoids 3-6 displayed a much stronger cytotoxicity against cell lines HeLa, MCF-7, and P-388 with an $\mathrm{IC}_{50} \leq 1.0 \mu \mathrm{g} / \mathrm{mL}$. On the other hand, compounds 7-9 were found inactive against all cell

- Table $1{ }^{13} \mathrm{C}$ and ${ }^{1} \mathrm{H}$ NMR (150 and $\left.600 \mathrm{MHz}\right)$ data of $\mathbf{1}$ and $\mathbf{2}\left(\mathrm{CDCl}_{3}, \delta\right.$ in ppm, $J$ in $\mathrm{Hz}$ ).

\begin{tabular}{|c|c|c|c|c|}
\hline & \multicolumn{2}{|r|}{1} & \multicolumn{2}{|r|}{2} \\
\hline No. & $\delta_{\mathrm{C}}$ & $\delta_{\mathrm{H}}$ & $\delta_{\mathrm{C}}$ & $\delta_{\mathrm{H}}$ \\
\hline \multirow[t]{2}{*}{1} & 36.2 & $2.55 \mathrm{~d}(17.9)$ & 35.4 & $2.24 \mathrm{~d}(6.2)$ \\
\hline & & $2.26 \mathrm{~d}(17.9)$ & & $2.23 \mathrm{~d}(11.0)$ \\
\hline 2 & 126.4 & & 68.4 & $4.28 \mathrm{dd}(11.0,6.2)$ \\
\hline 3 & 130.4 & & 70.6 & \\
\hline \multirow[t]{2}{*}{4} & 30.8 & $\begin{array}{l}2.17 \mathrm{dd}(17.2, \\
5.5)\end{array}$ & 36.9 & $1.93-1.95 \mathrm{~m}$ \\
\hline & & $2.00-203 \mathrm{~m}$ & & $1.78-1.81 \mathrm{~m}$ \\
\hline \multirow[t]{2}{*}{5} & 31.2 & $1.92 \mathrm{td}(12.4,5.5)$ & 23.8 & $1.97-1.99 \mathrm{~m}$ \\
\hline & & $\begin{array}{l}1.76 \mathrm{ddt}(12.4, \\
4.8,2.1)\end{array}$ & & $1.78-1.81 \mathrm{~m}$ \\
\hline 6 & 46.2 & & 47.5 & \\
\hline 7 & 171.1 & & 168.7 & \\
\hline 8 & 124.1 & $6.32 \mathrm{~s}$ & 124.5 & $6.18 \mathrm{~s}$ \\
\hline 9 & 199.3 & & 199.1 & \\
\hline \multirow[t]{2}{*}{10} & 49.8 & $2.64 \mathrm{~d}(17.2)$ & 50.6 & $2.41 \mathrm{~d}(19.3)$ \\
\hline & & $2.10 \mathrm{~d}(17.2)$ & & $2.36 \mathrm{~d}(19.3)$ \\
\hline 11 & 41.3 & & 41.6 & \\
\hline $12^{*}$ & 25.2 & $1.06 \mathrm{~s}$ & 28.1 & $1.16 \mathrm{~s}$ \\
\hline $13^{*}$ & 24.6 & $0.96 \mathrm{~s}$ & 27.9 & $1.13 \mathrm{~s}$ \\
\hline \multirow[t]{2}{*}{14} & 64.0 & $4.24 \mathrm{~s}$ & 63.9 & $4.46 \mathrm{~d}(16.5)$ \\
\hline & & & & $4.42 \mathrm{~d}(16.5)$ \\
\hline 15 & 20.4 & $1.79 \mathrm{~s}$ & 29.3 & $1.36 \mathrm{~s}$ \\
\hline
\end{tabular}

lines. Compounds $\mathbf{1}$ and $\mathbf{2}$ exhibited weak activity against Bacillus cereus with MIC and MBC values of 250 and $1000-1250 \mu \mathrm{g} / \mathrm{mL}$, respectively $>$ Table $\mathbf{3}$ ). In a previous literature, compound $\mathbf{3}$ was reported as having no activity against NO and TNF- $\alpha$ production in LPS-induced RAW 264.7 macrophages, and no antibacterial property on Mycobacterium bovis [12]. Compounds 4 and $\mathbf{6}$ were reported to show antileishmanial activity against Leishmania amazonensis on promastigotes ( $\mathrm{IC}_{50}$ of 9.7 and $6.2 \mu \mathrm{g} / \mathrm{mL}$, respectively) and amastigotes ( $\mathrm{IC}_{50}$ of 4.5 and $3.9 \mu \mathrm{g} / \mathrm{mL}$, respectively), but were not active against NO production by macrophages [15]. In addition, compounds $\mathbf{4}$ and $\mathbf{6}$ were also reported to exhibit cytotoxic activities against gastric carcinoma $\left(\mathrm{IC}_{50}\right.$ of $<1.0$ and $7.0 \mu \mathrm{g} / \mathrm{mL}$, respectively), liver carcinoma $\left(\mathrm{IC}_{50}\right.$ of $\left.<1.0 \mu \mathrm{g} / \mathrm{mL}\right)$, and breast carcinoma (IC 50 of $<1.0$ and $1.5 \mu \mathrm{g} / \mathrm{mL}$, respectively), while 5 showed an $\mathrm{IC}_{50}$ of $1.0,0.25$, and $1.0 \mu \mathrm{g} / \mathrm{mL}$ on non-small lung cancer, human colon carcinoma, and melanoma cells, respectively. Compounds 4-6, however, showed negligible antibacterial activity [24].

\section{Materials and Methods}

\section{General experimental procedures}

The ${ }^{1} \mathrm{H}$ NMR $(600 \mathrm{MHz})$ and ${ }^{13} \mathrm{C}$ NMR $(150 \mathrm{MHz})$ spectra were recorded on an NMR spectrometer (Jeol). The HRESIMS was acquired via LCMS-ESI-IT-TOF (Shimadzu). An AUTOPOL IV automatic polarimeter was used to measure the optical rotation (Rudolph Research Analytical). Infrared spectra were recorded on an FTIR (Thermo Nicolet). For preparative TLC (Kieselgel $60 \mathrm{~F}_{254}$, Merck), the spots were visualized by UV light (254 and $365 \mathrm{~nm}$ ) and spraying with a $5 \%$ phosphomolybdic acid-ethanol solution. Column chromatography was performed with silica gel (Kieselgel 60, 70230 mesh; Merck). All organic solvents for extraction and isolation were of analytical grade (Fisher Scientific). The HPLC solvent was HPLC grade (Fisher Scientific). The deuterated $\mathrm{CDCl}_{3}$ was purchased from Merck.

\section{Plant material}

Specimens of L. majuscula (Harvey) Lucas were collected from Mantanani Island, Sabah (0659.728'N, 116³4.830'E) in November 2017. A voucher specimen (BORH39093) was deposited in the BORNEENSIS Collection of the Institute for Tropical Biology and Conservation, University of Malaysia, Sabah. Field identifications were done by Prof. Dr. Charles S. Vairappan, who is the corresponding author of this paper. Voucher specimens were examined by Assoc. Prof. Dr. Abe Tsuyoshi, Hokkaido University Museum, Sapporo, Japan.

- Table 2 Cytotoxicity of compounds 1-9 against cancer cell lines HeLa, MCF-7, and P-388.

\begin{tabular}{|l|l|l|l|l|l|l|l|l|l|}
\hline \multirow{2}{*}{ Cells } & \multicolumn{9}{c|}{$\mathbf{I C}_{\mathbf{5 0}}(\boldsymbol{\mu g} / \mathbf{m L})$} \\
\cline { 2 - 11 } & $\mathbf{1}$ & $\mathbf{2}$ & $\mathbf{3}$ & $\mathbf{4}$ & $\mathbf{5}$ & $\mathbf{6}$ & $\mathbf{7}$ & $\mathbf{8}$ & $\mathbf{9}$ \\
\hline HeLa & 2.50 & 2.50 & 0.75 & 0.75 & 1.00 & 1.00 & - & - & - \\
\hline MCF-7 & 2.50 & 5.00 & 1.00 & 0.75 & 0.75 & 1.00 & - & - & - \\
\hline P-388 & 5.00 & 2.50 & 0.75 & 1.00 & 1.00 & 1.00 & - & - & - \\
\hline
\end{tabular}


- Table 3 Antibacterial activities of compounds $\mathbf{1}$ and $\mathbf{2}$ against clinical strains.

\begin{tabular}{|l|l|l|}
\hline \multirow{2}{*}{ Strains } & \multicolumn{2}{|c|}{ MIC (MBC) in $\boldsymbol{\mu g} / \mathbf{m L}$} \\
\cline { 2 - 3 } & $\mathbf{1}$ & $\mathbf{2}$ \\
\hline Bacillus cereus & $250(1000)$ & $250(1250)$ \\
\hline Escherichia coli & - & - \\
\hline Salmonella typhi & $>500$ & $>500$ \\
\hline Vibrio cholera & $>500$ & $>500$ \\
\hline \multicolumn{2}{|c|}{ Positive control = kanamycin, with an MIC and MBC of $2.0 \mu \mathrm{g} / \mathrm{mL}$} \\
\hline
\end{tabular}

\section{Extraction and isolation}

After air drying for 3 days, the alga (110 g) was extracted with methanol $(\mathrm{MeOH})$. The resulting $\mathrm{MeOH}$ extract was concentrated in vacuo and partitioned between ethyl acetate (EtOAc) and $\mathrm{H}_{2} \mathrm{O}$. The EtOAc fraction was washed with water, dried over anhydrous $\mathrm{Na}_{2} \mathrm{SO}_{4}$, and evaporated to leave a dark green oil (3.0 g). The EtOAc extract (1.5 g) was then fractionated by $\mathrm{Si}$ gel column chromatography with a step gradient (hexane and EtOAc). The fraction eluted with hexane-EtOAc (8:2) was subjected to preparative TLC with toluene to give compounds 4 ( $160 \mathrm{mg}: 10.7 \%$ ), 5 (99 mg: $6.6 \%), 6$ (90 mg: $6.0 \%), 7$ (101 mg: $6.7 \%$ ), and 9 (41 mg: $2.7 \%$ ). The fraction eluted with hexane-EtOAc (7:3) was subjected to preparative TLC with chloroform $\left(\mathrm{CHCl}_{3}\right)$ to give 3 (41 mg: $2.7 \%$ ). The fraction eluted with hexane-EtOAc (1:1) was subjected to preparative TLC with $\mathrm{CHCl}_{3}$ to give 8 ( $82 \mathrm{mg}: 5.5 \%$ ). The fraction eluted with EtOAC (100\%) was subjected to preparative TLC with $\mathrm{CHCl}_{3}-\mathrm{MeOH}(95: 5)$ to give $\mathbf{1}$ (16 mg: $1.1 \%$ ) and $\mathbf{2}$ (15 mg: $1.0 \%$ ). Compounds that were isolated using the preparative TLC technique were further purified using reverse phase HPLC with an ODS-3 column under acetonitrile, $\mathrm{MeCN}-\mathrm{H}_{2} \mathrm{O}(50-100 \% \mathrm{MeCN})$, at $210 \mathrm{~nm}$ UV detection. Yields were calculated as a percentage of the EtOAc crude extract.

Lauremantanone A (1): colorless oil; $[\alpha]^{28}{ }_{\mathrm{D}}+22.3$ (c 1.0, $\mathrm{CHCl}_{3}$ ); IR (neat) $v_{\max } 3420,2930,1650,1455,1318,1078$, and $979 \mathrm{~cm}^{-1}$; ${ }^{1} \mathrm{H}$ and ${ }^{13} \mathrm{C} \mathrm{NMR}\left(\mathrm{CDCl}_{3}\right)$ spectral data: see - Table $1 ; \mathrm{HRESIMS} \mathrm{m/z}$ 269.1305 [M + H] ${ }^{+}$(calcd. for $\mathrm{C}_{15} \mathrm{H}_{22} \mathrm{ClO}_{2}, 269.1303$ ).

Lauremantanone B (2): colorless oil; $[\alpha]^{28}-35.0$ (c $\left.0.5, \mathrm{CHCl}_{3}\right)$; IR (neat) $v_{\max } 3444,2925,1651,1455$, and $1118 \mathrm{~cm}^{-1} ;{ }^{1} \mathrm{H}$ and ${ }^{13} \mathrm{C}$ $\operatorname{NMR}\left(\mathrm{CDCl}_{3}\right)$; spectral data: see > Table 1; HRESIMS m/z 287.1412 $[\mathrm{M}+\mathrm{H}]^{+}$(calcd. for $\mathrm{C}_{15} \mathrm{H}_{24} \mathrm{ClO}_{3}, 287.1409$ ).

$(+)$-Laurencenone B (7): white powder; $[\alpha]^{25}{ }_{D}+39.4$ (c 0.2 , $\left.\mathrm{CHCl}_{3}\right) ;{ }^{1} \mathrm{H}$ NMR $\left(\mathrm{CDCl}_{3}, 600 \mathrm{MHz}\right) \delta: 5.89(1 \mathrm{H}, \mathrm{s}), 2.54-2.62(2 \mathrm{H}$, br m), $2.27(1 \mathrm{H}, \mathrm{d}, J=17.2 \mathrm{~Hz}), 2.16-2.20(1 \mathrm{H}, \mathrm{br} \mathrm{m}), 2.02-2.09$ $(2 \mathrm{H}, \mathrm{br} \mathrm{m}), 1.97(3 \mathrm{H}, \mathrm{s}), 1.93(1 \mathrm{H}, \mathrm{td}, J=12.7,5.6 \mathrm{~Hz}), 1.81(3 \mathrm{H}$, s), 1.75-1.77 (1H, br m), $1.06(3 \mathrm{H}, \mathrm{s}), 0.97(3 \mathrm{H}, \mathrm{s}) ;{ }^{13} \mathrm{C} \mathrm{NMR}\left(\mathrm{CDCl}_{3}\right.$, $150 \mathrm{MHz}$ ) $\delta:$ 198.1, 168.5, 129.7, 127.5, 126.3, 48.9, 46.4, 40.5, 36.3, 30.4, 30.2, 24.8, 23.8 (overlapped two signals), 19.7.

\section{Cytotoxic assay}

The in vitro cytotoxicity assay was conducted against the cell lines human cervical epithelioid carcinoma (HeLa), human breast carcinoma (MCF-7), and murine lymphocytic leukemia (P-388). The tested concentrations were $100,10,1,0.1,0.01$, and $0.001 \mu \mathrm{g} / \mathrm{mL}$. The assay was carried out using a previous procedure [25]. Positive control experiments were conducted using $\mathrm{H}_{2} \mathrm{O}_{2}$ as the test chemical.

\section{Antibacterial assay}

The antibacterial assay was carried out using 96-well plates with a known microdilution method against the strains Bacillus cereus (QEB2018-01), Escherichia coli (QEB2018-02), Salmonella typhi (QEB2018-03), and Vibrio cholera (QEB2018-04) obtained from Queen Elizabeth General Hospital, Kota Kinabalu, Sabah, Malaysia. The tested concentrations were 500, 250, 125, 62.5, 31.3, 15.6, $7.8,3.9$, and $2.0 \mu \mathrm{g} / \mathrm{mL}$. The assay was carried out using a previous procedure [6]. The positive control kanamycin (contained $\geq 98 \%$ kanamycin A) was purchased from Merck.

\section{Supporting Information}

NMR spectra of the new compounds are available as Supporting Information.

\section{Acknowledgements}

The authors would like to acknowledge Assoc. Prof. Dr. Toshiyuki Hamada (Kagoshima University) and Assoc. Prof. Dr. Takahiro Ishii (University of the Ryukyus) for the database search. This study was supported from grants GL0070, ERGS0040-STWN-1-2013, and ESPEC Foundation for Global Environment Research and Technology (Charitable Trust).

\section{Conflict of Interest}

The authors declare no conflict of interest.

\section{References}

[1] Suzuki M, Vairappan CS. Halogenated secondary metabolites from Japanese species of the red algal genus Laurencia (Rhodomelaceae, Ceramiales). Curr Top Phytochemistry 2005; 5: 1-38

[2] Wang BG, Gloer JB, Ji NY, Zhao JC. Halogenated organic molecules of Rhodomelaceae origin: Chemistry and biology. Chem Rev 2013; 113 : 3632-3685

[3] Ji NY, Wang BG. Nonhalogenated organic molecules from Laurencia algae. Phytochem Rev 2014; 13: 653-670

[4] Wanke T, Philippus AC, Zatelli GA, Vieira LFO, Lhullier C, Falkenberg M. C15 acetogenins from the Laurencia complex: 50 years of research-an overview. Revista Brasileira de Farmacognosia 2015; 25: 569-587

[5] Fenical W. Chemical variation in a new bromochamigrene derivative from the red seaweed Laurencia pacifica. Phytochemistry 1976; 15 : 511-512

[6] Vairappan CS. Potent antibacterial activity of halogenated metabolites from Malaysian red algae, Laurencia majuscula (Rhodomelaceae, Ceramiales). Biomol Eng 2003; 20: 255-259

[7] Kamada T, Vairappan CS. Non-halogenated new sesquiterpenes from Bornean Laurencia snackeyi. Nat Prod Res 2017; 31: 333-340

[8] Kamada T, Phan CS, Vairappan CS. New anti-bacterial halogenated tricyclic sesquiterpenes from Bornean Laurencia majuscula (Harvey) Lucas. Nat Prod Res 2019; 33: 464-471

[9] Kamada T, Phan CS, Sien ST, Vairappan CS. Halogenated chamigrane sesquiterpenes from Bornean Laurencia majuscula. J Appl Phycol 2018; 30: $3373-3378$ 
[10] Kamada T, Vairappan CS. New laurene-type sesquiterpene from Bornean Laurencia nangii. Nat Prod Commun 2015; 10: 843-844

[11] Ishii T, Nagamine T, Nguyen BCQ, Tawata S. Insecticidal and repellent activities of laurinterol from the Okinawan red alga Laurencia nidifica. Rec Nat Prod 2017; 11: 63-68

[12] da Silva Machado FL, Ventura TL, Gestinari LM, Cassano V, Resende JA, Kaiser CR, Lasunskaia EB, Muzitano MF, Soares AR. Sesquiterpenes from the Brazilian red alga Laurencia dendroidea J. Agardh. Molecules 2014; 19: 3181-3192

[13] Brennan MR, Erickson KL, Minott DA, Pascoe KO. Chamigrane metabolites from a Jamaican variety of Laurencia obtusa. Phytochemistry 1987; 26: 1053-1057

[14] Francisco MEY, Turnbull MM, Erickson KL. Cartilagineol, the fourth lineage of Laurencia-derived polyhalogenated chamigrene. Tetrahedron Lett 1998; 39: 5289-5292

[15] da Silva Machado FL, Lima WP, Bergmann BR, Gestinari LMS, Fujii MT, Paula JC, Costa SS, Lopes NP, Kaiser CR, Soares AR. Antileishmanial sesquiterpenes from the Brazilian red alga Laurencia dendroidea. Planta Med 2011; 77: 733-735

[16] Machado FLS, Duarte HM, Gestinari LMS, Cassano V, Kaiser CR, Soares AR. Geographic distribution of natural products produced by the red alga Laurencia dendroidea J. Agardh. Chem Biodivers. 2016; 13: 845-851

[17] González AG, Martín JD, Martín VS, Norte M. Carbon-13 NMR application to Laurencia polyhalogenated sesquiterpenes. Tetrahedron Lett 1979; 29: 2719-2722
[18] White DE, Stewart IC, Grubbs RH, Stoltz BM. The catalytic asymmetric total synthesis of elatol. J Am Chem Soc 2008; 130: 810-811

[19] White DE, Stewart IC, Seashore-Ludlow BA, Grubbs RH, Stoltz BM. A general enantioselective route to the chamigrene natural product family. Tetrahedron 2010; 66: 4668-4686

[20] Faulkner DJ. Marine natural products. Nat Prod Rep 1988; 5: 613-663

[21] Vazquez JT, Chang M, Nakanishi K. Novel sesquiterpenes from Laurencia obtusa. Structure elucidation and absolute configuration and conformation based on circular dichroism. J Nat Prod 1988; 51: $1257-1260$

[22] Kennedy D], Selby IA, Thomson RH. Chamigrane metabolites from Laurencia obtusa and L. scoparia. Phytochemistry 1988; 27: 1761-1766

[23] Liu CM, Zhu RL, Liu RH, Li HL, Shan L, Xu XK, Zhang WD. Cis-clerodane diterpenoids from the liverwort Gottschelia schizopleura and their cytotoxic activity. Planta Med 2009; 75: 1597-1601

[24] Wessels M, König GM, Wright AD. New natural product isolation and comparison of the secondary metabolite content of three distinct samples of the sea hare Aplysia dactylomela from Tenerife. J Nat Prod 2000; 63: 920-928

[25] WAJP Wijesinghe, Jeon Y], Ramasamy P, Wahid MEA, Vairappan CS. Anticancer activity and mediation of apoptosis in human $\mathrm{HL}-60$ leukemia cells by edible sea cucumber (Holothuria edulis) extract. Food Chem 2013; 139: 326-331 